\title{
Disclosure Annual General Meeting Minutes on the Corporate Website: A Panacea toward a Good Governance
}

\author{
Mohd Shazwan Mohd Ariffn ${ }^{1 *}$, Wan Nordin Wan Hussin ${ }^{1}$, Siti Seri Delima Abdul Malak ${ }^{2}$ \\ 1 Othman Yeop Abdullah Graduate School of Business, Universiti Utara Malaysia \\ 2 Tunku Puteri Intan Safinaz School of Accountancy, Universiti Utara Malaysia, Malaysia
}

\begin{abstract}
Annual general meeting or known as AGM as the place for the management and shareholders to sit together to discuss the company with the objective of profit maximization and to promote organizational accountability. Based on the observation from a period of 2012 to 2017, the disclosure of AGM minutes on the corporate website increase over the year. However, the number is still below $50 \%$ in overall Malaysian public listed companies. This paper aims to highlight the importance of AGM minutes as one of the key success factors toward good governance. Based on this paper, the management of the company such as the board of directors, the company secretary, and related parties will take the initiative to publish good quality of AGM minutes as a panacea toward good governance.
\end{abstract}

Keywords: Annual General Meeting; Minutes; Key Matters; Corporate Website; Public Listed Companies

JEL Classification: G30

Paper Type: Conceptual Paper

\section{INTRODUCTION}

Minority Shareholders Watch Group (MSWG) established in the year 2000 intending to protect the interest of minority shareholders, such as during the annual general meeting (AGM) events. In addition to that, MSWG also promotes shareholders' activism, especially during the discussion at the general meeting. This study used ASEAN Corporate Governance Scorecard as a tool to benchmark the good quality of public listed companies. Its idea comes from ASEAN Capital Market Forum based on the six countries such as Malaysia, Thailand, Singapore, Philippines and Vietnam toward an international best practices (Malaysia-ASEAN Corporate Governance Report 2015, 2017).

Disclosure AGM minutes are voluntary in Malaysia until 2016, where Bursa Malaysia Berhad makes it compulsory for all public listed companies. These companies are required to publish a summary of the key matters discussed at the AGM as soon as possible after

* Corresponding author: E-mail: mohd_shazwan1@oyagsb.uum.edu.my, Phone: +6013-9739964 
the conclusion of the AGM (Chapter 9.21 Paragraph 2(b) of the Bursa Malaysia Berhad, Listing Requirement, 2016).

The term key matters and minutes always used simultaneously even though both provide a different meaning. Key matters based on Bursa Malaysia Berhad can be defined as a summary of the discussions or explanations on the matters set out in the agenda, substantial or pertinent comments on queries from shareholders relating to the agenda and responses from the board and management to the corporate website (Issuers Communication Corporate Website for Listed Issuers, ICN 1/2018, p. 2).

AGM minute is a formal record that provides the total voting results together with total vote counts of each agenda item for the shareholders especially those that unable to attend the event or potential investors of the company (The Malaysian Association of the Institute of Chartered Secretaries and Administrators, 2016). Simon Mort (1991) divided minutes into four purposes namely (a) a reminder of what happened at the last meeting, (b) providing a basis for discussion of matters arising, (c) a quick recall for those who were not present at the last meeting and (d) providing a permanent record. Furthermore, he also mentioned that minutes served as a conventional and formal meeting with an appointed chairman and secretary at the meeting.

Due to the separation between key matters and AGM minutes, this paper will focus on the AGM minutes because of the publication of the AGM minutes on the corporate website still a voluntary disclosure. Despite a voluntary disclosure, it was shown that Bursa Malaysia Berhad practice itself of AGM minutes instead of a summary of key matters. Bursa Malaysia Berhad is the leading of good governance and a regulatory body that monitors and surveillance all public listed companies in Malaysia consist of Main Market, ACE Market, and LEAP Market. By looking at Bursa Malaysia Berhad AGM minutes as a benchmark, it provides a detailed, full disclosure related to corporate information, a recommendation based on Malaysia Code on Corporate Governance practice and a brief record of the documents. This paper intends to stress the importance of the AGM minutes even though as a voluntary disclosure that indicates good quality of the information for the shareholders and potential investors.

According to ASEAN CG Scorecard, the assessment of voluntary disclosure among Malaysia public listed companies comprised of the appointment of women on board, increase the level of corporate responsibility statement, disclosure of board charter, code of ethics and board assessment on the corporate website. AGM Minutes is one of the indicators of voluntary disclosure by the ASEAN CG Scorecard. 
Table 1: Table extract of Minority Shareholders Watch Group Report (Others Disclosure) of all Malaysia public listed companies between the period 2012 to 2017.

\begin{tabular}{|c|c|c|c|c|c|c|}
\hline Other Disclosure & $\begin{array}{c}2017 \\
(\%)\end{array}$ & $\begin{array}{c}2016 \\
(\%)\end{array}$ & $\begin{array}{c}2015 \\
(\%)\end{array}$ & $\begin{array}{c}2014 \\
(\%)\end{array}$ & $\begin{array}{c}2013 \\
(\%)\end{array}$ & $\begin{array}{c}2012 \\
(\%)\end{array}$ \\
\hline Companies provided Board Charter & 86 & 82 & 74 & 55 & 41 & 16 \\
\hline Companies displayed Code of Ethics & 60 & 57 & 48 & 34 & 26 & 23 \\
\hline Companies that published AGM minutes & 37 & 9 & 5 & 3 & 1 & 0.2 \\
\hline Companies that published M\&A & $\mathrm{n} / \mathrm{a}$ & $\mathrm{n} / \mathrm{a}$ & 5 & 3 & 3 & 2 \\
\hline Companies disclosed individual director remuneration & 11 & 10 & 9 & 8 & 9 & 15 \\
\hline Companies provided Dividend Policy & $\mathrm{n} / \mathrm{a}$ & $\mathrm{n} / \mathrm{a}$ & 10 & 8 & 8 & 17 \\
\hline Companies provided Whistle Blowing Policy & $\mathrm{n} / \mathrm{a}$ & $\mathrm{n} / \mathrm{a}$ & 22 & 13 & 12 & 13 \\
\hline Companies provided Corporate Responsibility Policy & $\mathrm{n} / \mathrm{a}$ & $\mathrm{n} / \mathrm{a}$ & 73 & 67 & 64 & 75 \\
\hline $\begin{array}{l}\text { Companies disclosed training attended by each } \\
\text { Director }\end{array}$ & $\mathrm{n} / \mathrm{a}$ & $\mathrm{n} / \mathrm{a}$ & 60 & 50 & 50 & 49 \\
\hline Annual Financial Report released within 4 months & $\mathrm{n} / \mathrm{a}$ & $\mathrm{n} / \mathrm{a}$ & 89 & 88 & 85 & 81 \\
\hline
\end{tabular}

Source: MSWG Media Release, 2016, 2017.

Note: n/a means that non-applicable due to the adoption of Companies Act 2016.

Table 1 depicts that all Malaysia public listed companies aware of the importance of the voluntary disclosure of AGM minutes on the corporate website as from 2012 to 2015, almost all companies increase their level of disclosure. For the AGM minutes, the table shows a drastic increase in the disclosure from 0.2 percent in 2012 to 37 percent in 2017 (MSWG, 2018). The high level of disclosure of 37 percent, mainly due to the amended Chapter 9.21 Paragraph 2(b) of Bursa Malaysia Berhad. Whereby most of the public listed companies willing to disclose more information (in this case, AGM minutes) to attract new investors and promote greater transparency and accountability.

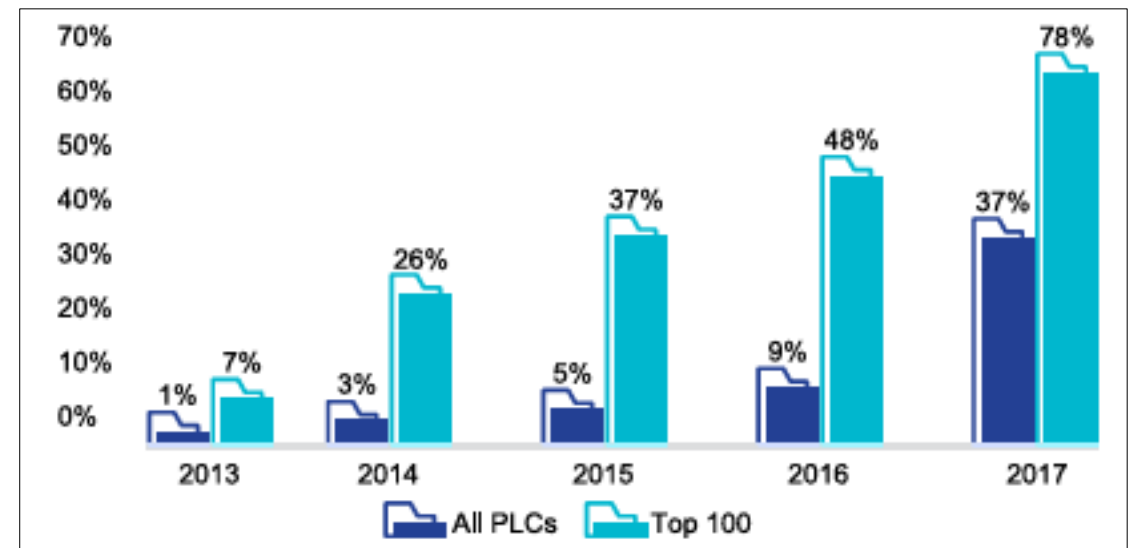

Figure 1. Publication of AGM minutes into the companies website between the period 2013 to 2017. Source: Re-print of the Malaysia-ASEAN CG Report 2017

From the Figure 1 based on the comparison between all public listed companies and top 100 companies from 2013 to 2017 reported by Malaysia ASEAN CG Report in 2017, compared to all public listed companies, the number of top 100 companies that published AGM minutes on corporate website increase over the years such as 7 percent (2013), 26 percent (2014), 37 percent (2015), 48 percent (2016) and 78 percent (2017) compared to 1 percent (2013), 3 percent (2014), 5 percent (2015), 9 percent (2016) and 37 percent (2017) for all public listed companies on the corporate website.

One possible reason for the difference mainly because the top 100 companies been monitored closely by the regulatory bodies such as Bursa Malaysia Berhad and Securities Commission of Malaysia which are more leniency for all public listed companies. Malaysia's top 100 companies comprise of the company with top market capitalisation 
weighted index that passes the size, free float and liquidity screens (FTSE Monthly Report, FTSE Russell, 2019). Compared to other ASEAN countries such as Thailand, Indonesia, Singapore, Philippines, and Vietnam, Malaysia is a unique country with corporate board diversity comprise of gender and nationality differences (Zainal, Zulkifli \& Saleh, 2013). As suggested by the study, the disclosure of AGM minutes on the corporate website could promote better governance based on several factors such as involvement of women directors and foreign directors that could bring a significant impact over the board diversity and decision-making process in Malaysia.

With Malaysia Institute of Corporate Governance (MICG) initiative toward transparency and accountability among public listed companies especially top 100 companies in Malaysia, strict regulations imposed by the Bursa Malaysia Berhad Listing Requirements, adopted of Malaysian Code on Corporate Governance 2017 and revised Companies Act 2016, a more disclosure indicate a clean sheet of the corporate information of the companies. Malaysia also learned to form the previous scandal and corporate failure in Malaysia and globally that provide a better precaution and more aggressive shareholders toward their ownership. The concept is clean, the more disclosure of the corporate information, the more transparency and accountability of the companies to its shareholders and potential investors.

\section{LITERATURE REVIEW}

Historically, there is a notable lack of empirical evidence on voluntary disclosure, especially involving AGM minutes worldwide. Disclosure can be defined as a signal for the companies to align with the current business environment (Brammer \& Pavelin, 2004). Disclosure can be divided into mandatory and voluntary types (Rouf, 2011; Akhtaruddin, 2005; Mahoney, 1995; Easterbrook \& Fischel, 1984). However, generally, most of the prior researchers tend to discuss the disclosure information from the mandatory perspective (Rouf, 2011). This is because most of the companies tend not to comply with the mandatory disclosure or comply with what is necessary only. Lacking the disclosure information becomes the main reason for this paper, especially from the perspective of voluntary disclosure.

Mandatory disclosure can be defined as the record of documentation information, rules by the regulation and provide an effective and efficient structure of the system (Healy \& Palepu, 2001). Among regulatory bodies that control and monitor the public listed companies in Malaysia such as Bursa Malaysia, Securities Commission of Malaysia and adhere to the Constitution governed by the Companies Commission of Malaysia. Their primary function is to control and monitor the trading transaction of each company in align with the rules and regulations policy. For example, disclosure of financial results, the outcome of the general meeting and the submission of the annual report to the Companies Commission of Malaysia are based on the date of incorporation (Syarikat Suruhanjaya Malaysia, 2019).

Voluntary disclosure is disclosure information beyond the mandatory requirement and not a violation of the acts, rules, and regulations. Among the voluntary disclosure such as disclosure AGM minutes on the corporate website, disclosure board charter, disclosure senior management directors remuneration, and so on. Their primary purpose is to bring a confidant to the existing shareholders and potential investors about the company's performance (Barako, Hancock \& Izan, 2006). The more disclose of corporate information indicates a good governance practice by the company. Voluntary disclosure generally associated with the best practice, recommendation and guideline to champion good governance such as Malaysia Code on Corporate Governance, Best Practice Guide on 
AGMs for Listed Issuers and Corporate Governance Guide (Bursa Sustain, 2019; The Malaysian Association of the Institute of Chartered Secretaries and Administrators, 2016).

Besides that, most of the voluntary disclosure information can be access through annual reports, corporate websites and management information (Wang, Sewon \& Claibrone, 2008; Bujaki \& McConomy, 2002). Interestingly, the more excessive information to the public shows that how responsible of the company to its shareholders. As such, from the shareholder's view, the extensive information compared to other company indicate the effectiveness of the business operation and how the company able to grow in the future. Besides, evidence support that disclosure can reduce asymmetry information, lower corruption index and enhance the profitability of the company.

Annual general meeting minutes are mandatory information that must be recorded, kept at the registered office and audit by the licensed audited every year. In this regard, the call for publication AGM minutes on the corporate website still voluntary as Bursa Malaysia Berhad only highlighted that every public-listed company must publish a summary of key matters to corporate website soonest possible after the meeting was held. As no standard format of summary key matters and key salient to be disclosed, each company can disclosure any corporate information that we willing to share with the public.

Besides Malaysia, ASEAN countries such as Thailand, Indonesia, Singapore, Philippines, and Vietnam also practice a unique disclosure of corporate information. For example, in Thailand, after the general meeting, the companies under the Stock Exchange of Thailand (SET) required detailed voting outcomes such as whether each resolution is carried or declined. The detailed of a company announcement and brief voting outcome (total number of shareholders voting for, against or abstaining the agenda and number of shares held) were also be required to be disclosed. This is similar to Listing Requirements in Malaysia in the Bursa Announcement column Outcome of the Meeting (The Malaysian Association of the Institute of Chartered Secretaries and Administrators, 2016; p. 76).

According to Malaysia-ASEAN Corporate Governance Report (2015), Indonesia Stock Exchange (IDX) practice very detailed minutes to be reported in their annual reports while for Thailand and the Philippines. Besides the strict stock exchange and own code on corporate governance, their rules required these countries to produce a brief and detailed explanation for each item in the AGM notice and comprehensive minutes.

To compare, each of the recommendations of the ASEAN counterpart already adheres and implemented in Malaysia since the amendment of Bursa Malaysia Berhad Listing Requirements in 2016 together with the adopted of the new Companies Act 2016. The similarity between each country, such as the regulatory highly encourages full disclosure of AGM minutes on the corporate website despite voluntary disclosure practice. In the long term, it indicates the high level of corporate governance initiative by each regulatory body with the support of professional agencies such as Minority Shareholders Watch Group and Institute of Investors such as in Malaysia.

\section{SIMILARITY AND COMPARISON BETWEEN ASEAN COUNTRIES}

Based on table 2 given, we can see the changing of the release Code on Corporate Governance from Malaysia, Thailand, Indonesia, Singapore, Philippines, and Vietnam for 2017. From Malaysia's perspective, the development of the Malaysia Code on Corporate Governance (the Code) started in 2000 introduced by Finance Committee on Corporate Governance focused on Working Group on Best Practices in Corporate Governance (Satkunasingam \& Ramasamy, 2003). The primary aim of the Code was to build a reform of standards of corporate governance in line with international standards to enable Malaysian companies to compete globally. 
Table 2: Comparative analysis between Malaysia, Thailand, Indonesia, Singapore, Philippines

\begin{tabular}{|c|c|c|c|c|c|c|}
\hline & Malaysia & Thailand & Indonesia & Singapore & Philippines & Vietnam \\
\hline $\begin{array}{l}\text { Stock } \\
\text { Exchange }\end{array}$ & $\begin{array}{l}\text { Bursa } \\
\text { Malaysia } \\
\text { Stock } \\
\text { Exchange } \\
\text { (KLSE) }\end{array}$ & $\begin{array}{l}\text { Stock } \\
\text { Exchange of } \\
\text { Thailand } \\
\text { (SET) }\end{array}$ & $\begin{array}{l}\text { Indonesia } \\
\text { Stock } \\
\text { Exchange } \\
\text { (IDX) }\end{array}$ & $\begin{array}{l}\text { Singapore } \\
\text { Exchange } \\
(\mathrm{SGX})\end{array}$ & $\begin{array}{l}\text { Philippine } \\
\text { Stock } \\
\text { Exchange } \\
\text { (PSE) }\end{array}$ & $\begin{array}{l}\text { Ho Chi } \\
\text { Minh Stock } \\
\text { Exchange } \\
\text { (HOSE) }\end{array}$ \\
\hline $\begin{array}{l}\text { Disclosure } \\
\text { AGM Minutes } \\
\text { On The } \\
\text { Corporate } \\
\text { Website }\end{array}$ & Voluntary & Voluntary & Voluntary & Voluntary & Voluntary & Voluntary \\
\hline $\begin{array}{l}\text { Top Publicly } \\
\text { Listed } \\
\text { Companies In } \\
\text { Asean* }\end{array}$ & $\begin{array}{l}\text { Bursa } \\
\text { Malaysia } \\
\text { Berhad }\end{array}$ & $\begin{array}{l}\text { PTT Global } \\
\text { Chemical } \\
\text { Limited }\end{array}$ & $\begin{array}{l}\text { Aneka } \\
\text { Tambang } \\
\text { Persero TBK }\end{array}$ & $\begin{array}{l}\text { DBS Group } \\
\text { Holdings }\end{array}$ & $\begin{array}{l}\text { Ayala Land } \\
\text { Inc. }\end{array}$ & $\begin{array}{l}\text { Ho Chi } \\
\text { Minh City } \\
\text { Securities }\end{array}$ \\
\hline $\begin{array}{l}\text { Code On } \\
\text { Corporate } \\
\text { Governance }\end{array}$ & $\begin{array}{l}\text { Malaysia } \\
\text { Code on } \\
\text { Corporate } \\
\text { Governance } \\
\text { (MCCG) }\end{array}$ & $\begin{array}{l}\text { Thailand } \\
\text { Corporate } \\
\text { Governance } \\
\text { for Listed } \\
\text { Companies }\end{array}$ & $\begin{array}{l}\text { Indonesia } \\
\text { Code of } \\
\text { Good } \\
\text { Governance } \\
\text { (GCG) }\end{array}$ & $\begin{array}{l}\text { Code of } \\
\text { Corporate } \\
\text { Governance } \\
\text { (CGC) }\end{array}$ & $\begin{array}{l}\text { Code of } \\
\text { Corporate } \\
\text { Governance } \\
\text { for Publicly } \\
\text { Listed } \\
\text { Companies } \\
\end{array}$ & $\begin{array}{l}\text { Vietnamese } \\
\text { Corporate } \\
\text { Governance } \\
\text { Manual }\end{array}$ \\
\hline $\begin{array}{l}\text { Year Of } \\
\text { Released }\end{array}$ & 2017 & 2017 & 2006 & 2018 & 2016 & 2018 \\
\hline $\begin{array}{l}\text { Act } \\
\text { (Companies } \\
\text { Incorporation) }\end{array}$ & $\begin{array}{l}\text { Companies } \\
\text { Act } 2016\end{array}$ & $\mathrm{~N} / \mathrm{A}$ & $\mathrm{N} / \mathrm{A}$ & $\begin{array}{l}\text { Companies } \\
\text { Act } 2014\end{array}$ & $\mathrm{~N} / \mathrm{A}$ & N/A \\
\hline $\begin{array}{l}\text { Corruption } \\
\text { Perceptions } \\
\text { Index } \\
\text { (Rank) }\end{array}$ & 55 & 101 & 90 & 7 & 101 & 113 \\
\hline
\end{tabular}

Meanwhile, in 2007, revised Malaysian Code on Corporate Governance introduced by Securities Commission of Malaysia in aligning with former Prime Minister, Dato' Seri Abdullah Ahmad Badawi speech, "the Code is being reviewed to improve the quality of the board of public listed companies by putting in place the criteria for qualification of directors and strengthening the audit committee, as well as the internal audit function of the public listed.... To ensure the effectiveness of the audit committee of public listed companies, executive directors will no longer be allowed to become members of the audit committee. In addition, the internal audit function will be mandated for all public listed companies, and the board of directors will be responsible for ensuring the adherence to the scope of internal audit functions...." (Badawi, 2016).

In 2012, the revised Code was established to supersede earlier edition (the Code 2000 and 2007) as a new approach to promote greater internalisation of corporate governance culture. Compare to the previous version, the Code in 2012 was introduced in conjunction with the Securities Commission of Malaysia Corporate Governance Blueprint in 2011 toward strengthening board structure and composition by encouraging more active participant roles of directors. Interestlingly, Lode \& Noh (2019) in her research titled, "Does Malaysian Code of Corporate Governance matter among family-controlled firms" found that low disclosure of directors' remuneration brings positive significant toward family-controlled firms that lead to investors attraction. Even though not mention on AGM minutes disclosure on the corporate website however the level of directors remuneration disclosure indicated the importance of voluntary disclosure especially from the roles of directors toward effective and efficient management of the company.

In fact, with the latest Code namely Malaysian Code on Corporate Governance 2017, Securities Commission introduced with several features such as Comprehend (C), Apply 
(A), Report $(R)=$ CARE. The objective is not only to combat corruption but also to build mutual trust between the companies and stakeholders by promoting meaningful disclosures (for example, AGM minutes on the corporate website) that enhance a culture of openness and mutual respect between companies and stakeholders (Securities Commission, 2017: p. 11-12). If referring to the agency theory itself, Jensen focused on the relationship between the firm ownership structure and firm performance whereby the agent (board of directors) must act in accordance with the principal behalf (stakeholders interest) (Jensen \& Meckling, 1976). A further agency problem arises once the conflict exists between the principal and the agent, mostly minority shareholders on the firm performance versus profitability goal.

Lode and Noh (2019) also compare agency theory and Malaysia-ASEAN Corporate Governance Transparency Index, Findings and Recognition 2016 based on three dimensions of governance and one dimension of transparency to examine on corporate governance practices toward monitoring and governing among family-controlled firms (Malaysia-Asean Corporate Governance Transparency Index, Findings And Recognition, 2016). It was found that the board of directors' structure is highly correlated with the director's remuneration and accountability that lead to effective communication with shareholders. By referring their research, this paper intends to highlight the importance of AGM minutes that mislook from other researchers' perspective and Malaysia as a unique country with different races, a mixture of culture and heritage can enhance good governance compared to another ASEAN region. This can be supported where Malaysia's corruption index is better compared to other Commonwealth countries such as Indonesia, Thailand, Philippines, Vietnam, except Singapore, which is ranking better from Malaysia. To compare, the similarity between Malaysia and Singapore such as amendment of Companies Act, Malaysia with new Companies Act 2016 and Singapore with the new Companies Act 2014 and Malaysia release revised Code on Corporate Governance in 2017 whereas Singapore released its new Code of Corporate Governance in 2018 indicate the seriousness of both countries toward good governance.

\subsection{Data Collection}

This paper examines the publicly listed companies in Malaysia that willingness to disclose their AGM minutes on the corporate website for the financial year ended December 31, 2016. The initial sample was 274 companies, and we excluded six companies with incomplete information or data that does not fulfil the criteria of this paper. The final sample with the required data is 268 companies listed under the Main Market Bursa Malaysia website (Bursa Malaysia on Main Market: Listing Requirements, 2018).

We collect the demographic profile of each director of the companies that confirm disclose AGM minutes on the corporate website and also a company profile such as notice of the AGM meeting, the outcome of the AGM meeting, Annual Reports and CG Report that available from Bursa Malaysia website.

Each of the items will be analysed, coded and extracted to Statistical Package for the Social Sciences or also known as IBM SPSS to analyse the statistical data. Besides that, data extracted from Datastreams such as the return of investment, return of assets, sales, net profit and total debt of each company will be used as the control variable measurement of this paper.

In order to strengthen the director's profile information, this paper will utilise data from Bloomberg database and each corporate website to validate directors' profiles such as age, nationality, position, tenure as directors of the companies, number of shareholdings and higher education level. 


\subsection{Model Specification and Measurement}

Disclosure of AGM minutes on a corporate website can be divided into two categories consist of "full AGM minutes" and "extract AGM minutes or Key Matters Discussed". The heading of the minutes will be indicated whether the minutes under which category. Most of the full AGM minutes will highlight the full attendance of the meeting, the time duration of the meeting, specific agenda discuss during the meeting, questions and answers from the shareholders, total voting results and close with the chairman signatory. Meanwhile, extract AGM minutes or Key Matters Discussed only highlighted the agenda discuss during the meeting, questions and answers from the shareholders and total voting results.

The dichotomous scale of measurement coded " 1 " or " 0 " will be used to evaluate the level of disclosure. Whereby those publicly listed companies that published AGM minutes will be coded as 1 means disclose and 0 for otherwise. The dichotomous scale based on ASEAN CG Scorecard developed by ASEAN Capital Markets Forum and Asian Development Bank (Bank, 2016).

\section{CONCLUSION}

This paper intends to highlight the importance of disclosure AGM minutes on the corporate website as one of the keys to a good governance practice. Even though an observation shows that the disclosure of AGM minutes on corporate website increase over the year from 0.2 percent in 2012 to 37 percent in 2017, still more than half of all publicly listed companies did not provide AGM minutes on the corporate website.

From the top 100 companies, the year of 2013 indicated 7 percent disclosure and increased to 78 percent disclosure in the year 2017 . This is mainly due to the Government monitoring and surveillance toward the top 100 Malaysian public listed companies as a benchmark to other public listed companies. Besides that, for the top 100 companies, most of the regulatory bodies and statutory bodies put an extra effort to ensure their practice of good governance beyond the requirements. For example, each of the top 100 companies must follow and adopt the Malaysian Code on Corporate Governance into their management of the company and Malaysia Corporate Governance Guide version 3 released in 2017 as their governance practice. If the company did not comply with the requirements, the company must provide a brief explanation for non-compliance.

Meanwhile, to champion good governance initiatives by Malaysian Institute of Chartered Secretaries and Administrators (MAICSA), every public listed companies regardless top 100 companies or otherwise must adopt a good practice of corporate governance through a yearly observation of each directors performance, evaluation of independent directors roles and mitigation of risk management and internal control system. For example, the Securities Commission and Companies Commission of Malaysia will reveal those directors or companies that breach its corporate governance practice to the corporate website to educate and lesson for the other companies of the importance compliance to the rules and regulations.

Minority Shareholders Watch Group also act as a check and balance for the minority shareholders in order to avoid their right and power been supersede by the majority shareholders and to be accountability and transparency of each Malaysian publicly listed companies regardless top 100 or otherwise. Compare to other Commonwealth countries such as Indonesia, Thailand, Singapore, Vietnam, and the Philippines, Malaysia has a very active regulatory and statutory bodies and always promoting a good governance practice globally. 


\section{ACKNOWLEDGEMENTS}

The authors are very grateful for comments and suggestions from the anonymous referees and participants at the $6^{\text {th }}$ Annual EcoFI Symposium 2019 held on October $31^{\text {st }}, 2019$ at HIG Hotel, Langkawi, Kedah.

\section{REFERENCES}

Akhtaruddin, M. (2005). Corporate mandatory disclosure practices in Bangladesh. The International Journal of Accounting, 40(4), 399-422.

ASEAN Corporate Governance Scorecard Country Reports and Assesments (2016). Retrieved from https://www.mswg.org.my/sites/default/files/MSWG_2015_ASEAN_CG_SCORECARD_Web_version_ $0 . p d f$.

Badawi, A. B. H. A. (2016). Full Text of Speech by Prime Minister Datuk Seri Abdullah Bin Ahmad Badawi. Retrieved from https://www.thestar.com.my/news/nation/2007/12/10/full-text-of-speech-by-primeminister-datuk-seri-abdullah-bin-ahmad-badawi/

Bank, A. D. (2016). ASEAN Corporate Governance Scorecard Country Report And Assessment 2014. Retrieved from https://www.sc.com.my/api/documentms/download.ashx?id=82625e60-8595-427c8450f52800a2d47d.

Barako, D. G., Hancock, P., \& Izan, H. Y. (2006). Factors influencing voluntary corporate disclosure by Kenyan companies. Corporate Governance: an International Review, 14(2), 107-125.

Brammer, S., \& Pavelin, S. (2004). Voluntary social disclosures by large UK companies. Business Ethics: $A$ European Review, 13(2-3), 86-99.

Bujaki, M., \& McConomy, B. J. (2002). Corporate governance: Factors influencing voluntary disclosure by publicly traded Canadian firms. Canadian Accounting Perspectives, 1(2), 105-139.

Bursa Malaysia on Main Market: Listing Requirements (2016). Retrieved from http://www.bursamalaysia.com/market/regulation/rules/listing-requirements/mainmarket/listingrequirements.

Bursa Malaysia on Main Market: Listing Requirements (2018). Retrieved from http://www.bursamalaysia.com/market/regulation/rules/listing-requirements/mainmarket/listingrequirements.

Bursa Sustain (2019). Corporate Governance Guide. Retrieved from https://bursasustain.bursamalaysia.com/droplet-details/resources/corporate-governance-guide.

Cordery, C. J. (2005). The annual general meeting as an accountability mechanism. Retrieved from https://papers.ssrn.com/sol3/papers.cfm?abstract_id=1286930

$\begin{array}{ccccc}\text { Corruption } & \text { Perceptions } & \text { Index } & \text { Retrieved }\end{array}$ https://www.transparency.org/news/feature/corruption_perceptions_index_2016.

Easterbrook, F. H., \& Fischel, D. R. (1984). Mandatory disclosure and the protection of investors. Virginia Law Review, 70, 669.

FTSE Monthly Report, FTSE Russell (2019). Retrieved from https://www.ftserussell.com/indexseries/indexresources/index-reports.

Healy, P. M., \& Palepu, K. G. (2001). Information asymmetry, corporate disclosure, and the capital markets: A review of the empirical disclosure literature. Journal of Accounting and Economics, 31(1-3), 405-440.

Issuers Communication Corporate Website for Listed Issuers, ICN 1/2018 (2018). Retrieved from http://www.bursamalaysia.com/misc/system/assets/25717/ICN_1_2018\%20\%20GuidanceonCorporate WebsiteDisclosure.pdf.

Jensen, Michael C., \& William H. Meckling. (1976). Theory of the firm: Managerial behavior, agency costs and ownership structure. Journal of Financial, 3(4), 305-360.

Lode, N. A., \& Noh, I. M. (2019). Does Malaysian Code of Corporate Governance 'MCCG'matter among familycontrolled firms?. Journal of Advanced Research in Business and Management Studies, 12(1), 79-92.

Mahoney, P. G. (1995). Mandatory disclosure as a solution to agency problems. The University of Chicago Law Review, 62(3), 1047-1112.

Malaysia-ASEAN Corporate Governance Report (2015). Malaysia-ASEAN Corporate Governance Report in 2015. Retrieved from https://www.mswg.org.my/file/7338/download?token=11hGcpd8.

Malaysia-ASEAN Corporate Governance Report (2017). Malaysia-ASEAN Corporate Governance Report in 2017. Retrieved from https://www.mswg.org.my/file/7338/download?token=11hGcpd8.

Malaysia-ASEAN Corporate Governance Transparency Index, Findings And Recognition (2016). Special Focus, Malaysia. Retrieved from https://www.mswg.org.my/sites/default/ files/MSWG_1-4_V3.pdf. 
MSWG. (2018). MSWG-ASEAN Corporate Governance Recognition 2017. Retrieved from https://www.mswg.org.my/sites/default/files/AseanCG/2017/20171211_THE\%20EDGE\%20MALAYSIA $\% 20$ SPECIAL\%20REPORT.pdf.

MSWG Media Release. (2016). Malaysia-ASEAN Corporate Governance Transparency Index, Findings and Recognition 2016. Kuala Lumpur, Malaysia. Retrieved from https://www.mswg.org.my/sites/default/files/MEDIA\%20RELEASE_Final.pdf.

MSWG Media Release. (2017). MSWG-ASEAN Corporate Governance Recognition 2017. Retrieved from https://www.mswg.org.my/sites/default/files/ACG\%20Press\%20release.pdf

Malaysian Code on Corporate Governance 2012. (2012). Retrieved from http://micg.org.my/upload/file/articles/11/CODE-CG-2012.pdf.

Rouf, D. (2011). Corporate characteristics, governance attributes and the extent of voluntary disclosure in Bangladesh. African Journal of Business Management, 5(19), 7836-7845.

Satkunasingam, E., \& Ramasamy, N. (2003). Is the Malaysian Code of Corporate Governance 2000 an Effective Challenge to Cronyism? $5^{\text {th }}$ Asian Academy of Management Conference, 12-13.

Securities Commission. (2017). Malaysian Code on Corporate Governance 2012 (MCCG 2012). Retrieved from https://www.sc.com.my/api/documentms/download.ashx?id=82625e60-8595-427c-8450f52800a2d47d.

Securities Commission. (2018). Malaysian Code on Corporate Governance 2007 (MCCG 2007). Retrieved from https://issuance.sc.com.mygeneral_section/cg/.

Securities Commission. (2019). Malaysian Code on Corporate Governance 2017 (MCCG 2017). Retrieved from https://www.sc.com.my/api/documentms/download.ashx?id=6a514fb3-ebb4-473f-ac08$66690204 a 93 f$.

Simon Mort (1991). The Minutes-A Guide for Company Secretaries and Managers.

Syarikat Suruhanjaya Malaysia (2019), Retrieved from: http://www.ssm.com.my/Pages/faq.aspx.

The Malaysian Association of the Institute of Chartered Secretaries and Administrators (2016). Best Practice Guide on AGMs for Listed Issuers. 77-78. Retrieved from http://www.maicsa.org.my/download/publication/publication_agm.pdf

Wang, K., Sewon, O., \& Claiborne, M. C. (2008). Determinants and consequences of voluntary disclosure in an emerging market: Evidence from China. Journal of International Accounting, Auditing and Taxation, 17(1), 14-30.

Zainal, D., Zulkifli, N., \& Saleh, Z. (2013). Corporate board diversity in Malaysia: A longitudinal analysis of gender and nationality diversity. International Journal of Academic Research in Accounting, Finance and Management Sciences, 3(1), 136-148. 